\title{
Local Area Labor Statistics- A Phantom Army of the Unemployed?
}

\author{
G. J. Santoni
}

FFICLAL estimates of local area unemployment rates for 40 "small" (less populous) states, including those in the Eighth Federal Reserve District and the District of Columbia, registered a sharp increase relative to the national unemployment rate in the late 1970 s. $^{1}$ Subsequently, these unemployment rates remained higher than the national rate throughout the 1979-84 period, leading a number of observers to conclude that the problem of unemployment has become relatively more severe in these states. ${ }^{2}$

This shift is important. Federal grants to economically distressed areas depend, in part, on state unemployment estimates so, the shifting pattern of geographical unemployment can have significant consequences on the distribution of federal funds.

Chart 1 is a plot of seasonally adjusted quarterly unemployment rates in the Eighth Federal Reserve

G. J. Santoni is a senior economist at the Federal Reserve Bank of St. Louis. Thomas A. Pollmann provided research assistance.

The Eighth Federal Reserve District includes the state of Arkansas and parts of Missouri, tllinois, Indiana, Mississippi, Kentucky and Tennessee. Since data by county are not available in a convenient form and since the bulk of economic activity in the District is accounted for by the states of Arkansas, Kentucky, Missouri and Tennessee, references to the Eighth Federal Reserve District in this article include data from just these four states. The District's unemployment rate is a weighted average of state unemployment rates in which the weight for each state is the ratio of the state's labor force to the total (District) labor force.

see Szymczak (1984), Wagman (1984), Luecke (1984), Flaum (1984) and Ellis (1984).
District and the nation. With one exception, the two unemployment rates appear to track one another quite closely. Before 1979, the District's unemployment rate rose and fell in tandem with the national average though the District rate was lower. Beginning in 1979, however, the District's unemployment rate rose sharply relative to the nation's. Within one year, the unemployment rate in the Eighth District had risen above the national average. The sharp acceleration in District unemployment ceased in 1980 and has been tracking the national average since then, although at a higher level. The purpose of this article is to analyze this apparent shift in local area unemployment rates.

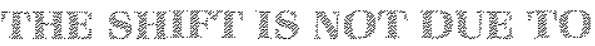

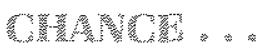

Table 1 compares the average quarterly differences between the unemployment rate in each District state and the national average before and after the fourth quarter of 1978. The unemployment rates in Kentucky, Missouri, Tennessee and the District as a whole are significantly below the national average during the earlier period, while Arkansas' unemployment rate does not differ significantly from the national average.

As can be seen from the table, these relationships changed substantially in the more recent period. Unemployment rates in Arkansas, Kentucky, Tennessee, as well as in the District, are significantly greater than 


\section{Chart 1}

\section{Unemployment Rate}

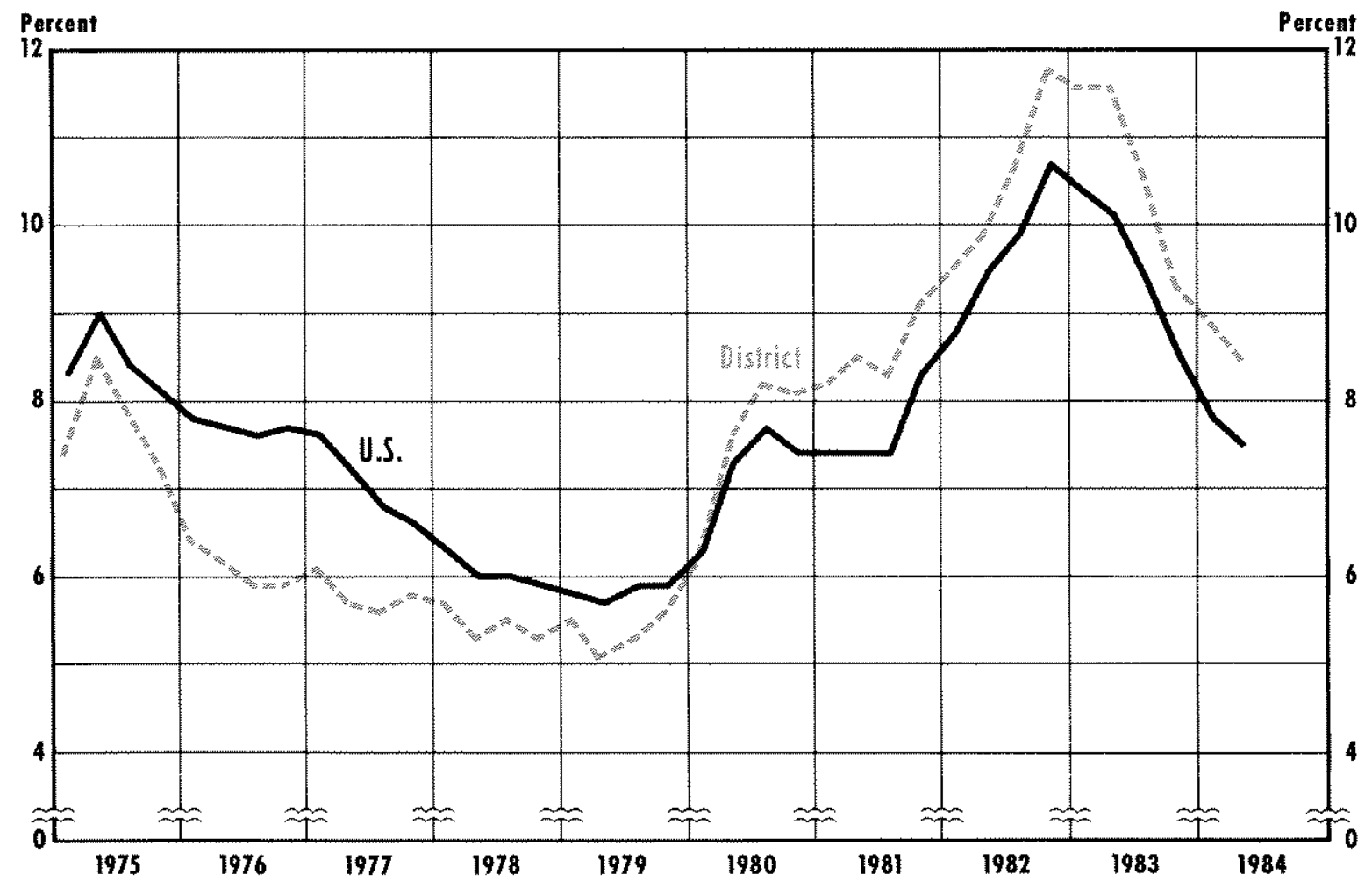

the U.S. average in the later period. The unemployment rate in Missouri, which had been significantly below the national average, does not differ significantly from the national average in the more recent period.

The data in table 1 indicate that the apparent shift in the relationship between District and national unemployment rates is probably not due to chance variation in the data, nor is it the result of a change in just one or two District states. Rather, it is systematic, occurring in each District state at about the same time.

\section{... MN W

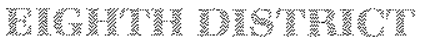

Chart 2 is similar to chart 1 except that the average unemployment rate for the 40 small states plus the
District of Columbia is plotted in place of the Eight District data. ${ }^{3}$ Notice that the average unemploymer rate in these states is also substantially below the $n c$ tional rate until 1979 when the difference between th two rates began to shrink.

While the average unemployment rate in thes states never rose above the national average, as it di in the District, the average difference between the tw rates fell by about .50 percentage points. ${ }^{4}$

3The states excluded from this sample are: California, Florida, II nois, Massachusetts, Michigan, New Jersey, New York, Ohi Pennsylvania and Texas. The average unemployment rate for th 40 small states and the District of Columbia is a weighted average which the weights are given by the method described in footnote 4The change is significant in a statistical sense $(t=9.42)$. 


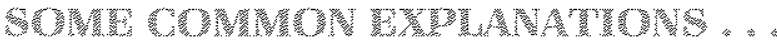

A number of explanations for the apparent shift in these relationships have been advanced. In most cases, analysts attribute the change to structural shifts in the national economy that have had large adverse consequences on particular states. Some believe that various geographic areas are not attracting an adequate share of new capital investment spending ${ }^{5}$ Others believe the structural shift is the result of the "international competitive situation" as well as "changes in federal fiscal policies and tax strategies.", Still others attribute it to "the shifting structure of the United States toward a service econorny" or to "employment-migration interactions." Each of these "maladies" suggests a particular cure, most of which carry substantial price tags."

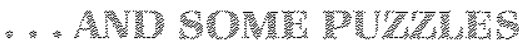

There are problems with these explanations, how ever. First, the shift is not apparent in other indicators of local area economic activity. For example, the relationship between the growth rates of total (and payroll) employment at the District and national levels show no break in the late 1970s. This is true of other indicators as well, such as the growth rates in District personal income, the value of total building and mortgage loans relative to national growth rates. $\mathrm{A}$ structural shift of the magnitude necessary to raise the average District unemployment rate by almost 2 percentage points relative to the national average would surely have been reflected in other indicators of relative economic performance.

Second, a structural change presumably would precipitate real wage adjustments and shifts in the geographic distribution of the labor force that would mitigate such unemployment discrepancies after a time. While real wages may be sticky in the short run, there is no reason for this stickiness to persist in the longer run. Real wage rates eventually will adjust, and labor

\footnotetext{
5See Szymczak (1984) and Wagman (1984).

"See Luecke (1984).

${ }^{7}$ See Kester (1984a) and (1984b), Greenwood and Hunt (1984), Flaum (1984) and Elis (1984).

${ }^{8}$ An exception is Clarkson and Meiners $(1977,1979)$ who have argued that the increase in the U.S. unemployment rate that occurred during the 1970 s can be attributed to work registration requirements imposed on welfare recipients. If welfare recipients are heavily concentrated in some states, this institutional change may have relevant implications for the problem discussed here. See, as well, O (1979) and Supel (1977).

See Santoni (1983).
}

\section{Table 1}

Average Quarterly Differences Between the Unemployment Rates in the United States, the District and Various District States

\begin{tabular}{|c|c|c|c|}
\hline & $\begin{array}{l}\text { listor } \\
\text { Average } \\
\text { diferenoe }\end{array}$ & tstat & Variance \\
\hline \multicolumn{4}{|l|}{08 minus } \\
\hline District & 1.022 & 9.08 & 0.21 \\
\hline Arransas & 40.056 & 0.27 & 0,67 \\
\hline Kentuoks & 11609 & 780 & 068 \\
\hline Missourt & 1326 & 1739 & 0.09 \\
\hline \multirow[t]{2}{*}{ Tennessee } & 0724 & 4,331 & 0.45 \\
\hline & \multicolumn{3}{|c|}{ 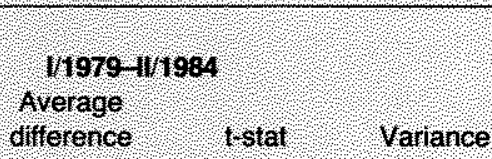 } \\
\hline \multicolumn{4}{|l|}{ Us. minus } \\
\hline Distict & 40.588 & 452 & 0.38 \\
\hline Gkansas & 40,637 & 4.93 & 0.37 \\
\hline Keniucky & 40937 & 538 & 067 \\
\hline Missour & 0.195 & 145 & 039 \\
\hline Tennessee & 41,137 & 574 & 0.86 \\
\hline
\end{tabular}

Signifieanty different from zero at the 5 percent level (fwo tailed (est).

will migrate to other geographic areas in which economic activity is more brisk. Both of these factors cause local area unemployment rates to adjust toward the national average as time passes. ${ }^{10}$

One implication of this argument is that, over time, the difference between local and national unemployment rates should shrink. The data plotted in chart 1 , however, do not appear to support this implication. In fact, after the shift, the difference between the District and U.S. unemployment rates increased as time passed. This can be shown by splitting the period $\mathrm{I}$ 1979-IV/1984 in half and comparing the average difference between the U.S. and District unemployment rates in the two subperiods. The mean difference during the first half was -.152 , while in the second half it was -968 . Thus, instead of shrinking, the difference

\footnotetext{
10 Of course, some difference between the unemployment rate in a particular local area and the national average may persist for a considerable period of time due to differences in the age (experience) mix of the population, for example, or differences in the structure of the labor market (extent of unionization) and industrial com position of the region.
} 
Chart 2

\section{Unemployment Rate}

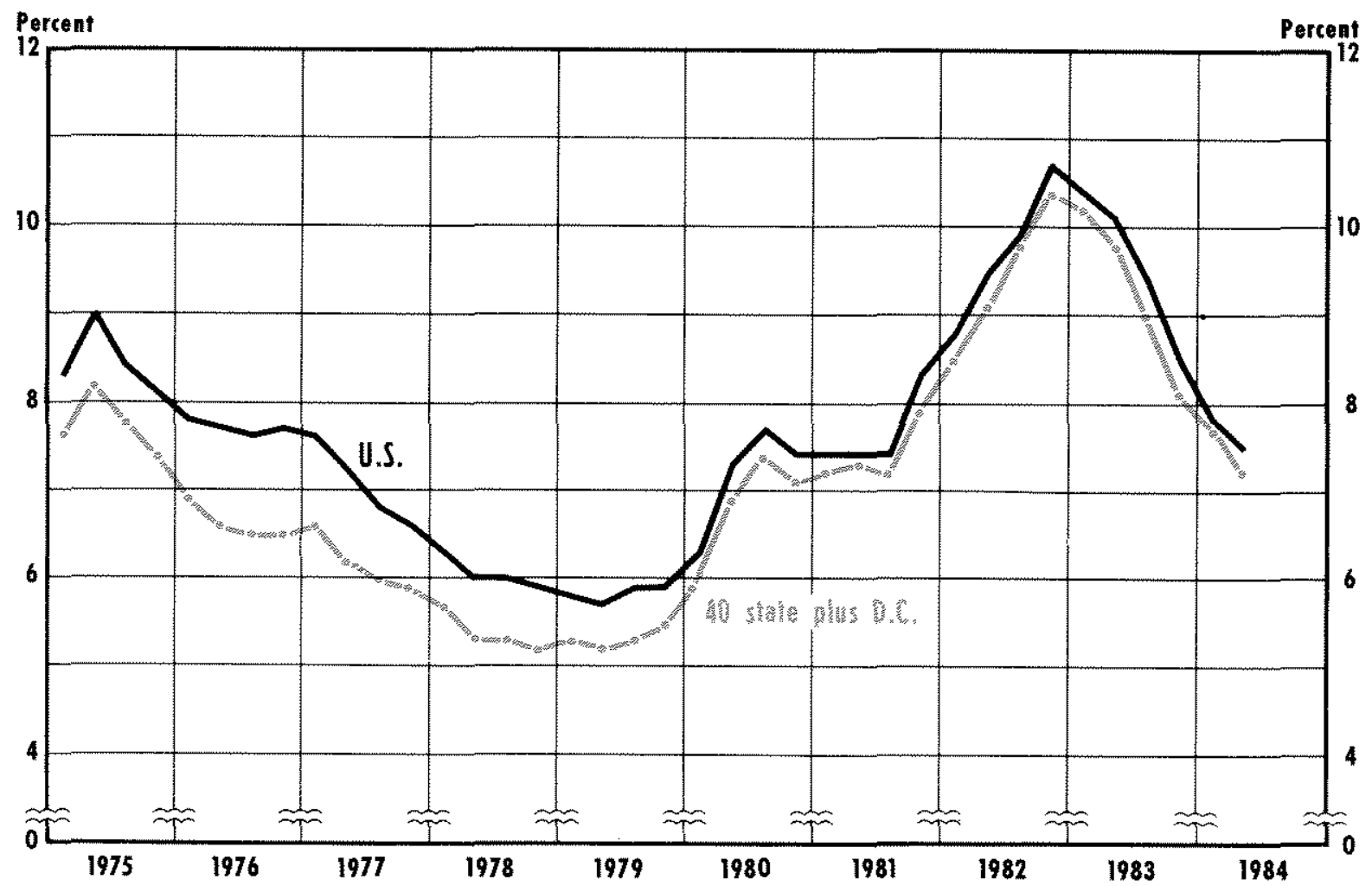

increased, and this increase is statistically significant."

The same argument can be applied with equal force to the earlier period running from $1 / 1970-I V / 1978$. If the difference between the U.S. and District unemployment rates during this period was due to some structural advantage that the District possessed, the difference should have gradually shrunk as District wage rates rose and labor migrated into the District from other geographic areas. This did not occur. Rather, there was an abrupt change in the late 1970s, when the District unemployment rate jumped above the national average. A similar argument applies in the case of the 40 small states and the District of Columbia. The average unemployment rate for these states was significantly below the national average until 1979 when, like the District's, it shot up relative to the national average.

${ }^{11}$ The t-statistic is 3.72 , which is significant at the 95 percent level.

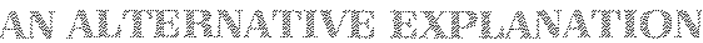

The hypothesis that the shift in the relationship between local and national unemployment rates is due to a change in the structure of the economy conflicts with other relevant data. The following analysis indicates that the 1979 shift in unemployment rates that occurred in the 40 small states and the District of Columbia was probably the result of a change in the method of estimating local area unemployment statistics. In short, pre- and post-1978 local unemployment rates are not comparable. The sharp rise in these local area unemployment rates is simply a statistical artifact.

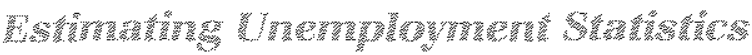

Currently, there are two different methods used to estimate unemployment statistics. Estimates of unemployment for the nation and for the 10 largest states 
are drawn directly from the Current Population Survey (CPS) ${ }^{32}$ For the remaining 40 states and the District of Columbia, estimates of unemployment are obtained by applying the "Handbook Method," which was developed by the Department of Labor in the 1950 s.

The two methods of estimating unemployment are like a pair of shoes. Both shoes perform a similar task but it pays to remember which is which. The CPS develops monthly estimates of unemployment for the United States and 10 large states by surveying 60,000 households during a one-week period containing the 12th day of the month. The week runs from Sunday through Saturday. ${ }^{13}$

The Handbook Method used by 40 states and the District of Columbia draws heavily on data from the unemployment insurance system for covered employment. An estimate of unemployment among workers who are not covered by unemployment insurance is added to this. This estimate of unemployment among uncovered workers is based primarily on historical national data and is referred to as a "synthetic" estimate by the Department of Labor. ${ }^{14}$

Prior to January 1978, all 50 states and the District of Columbia used the Handbook Method to estimate statewide unemployment rates, while the U.S. unemployment rate was estimated by the CPS. Since different estimating techniques were used, it is not surprising that observed statewide unemployment rates diverge from the U.S. "average" during this period. ${ }^{15}$

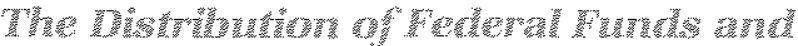

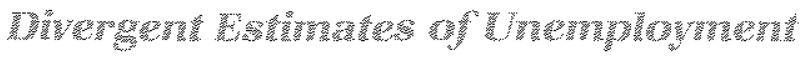

A second problem of noncomparability became particularly acute in the 1970s. While each state was using the Handbook Method to estimate unemployment

\footnotetext{
${ }^{2}$ See note 3 for a list of the 10 large states. The Current Population Survey is discussed further below.

'งU.S. Department of Labor (1982), pp. 3-4.

${ }^{14} \mathrm{For}$ additional information on this method of estimating unemployment, see U.S. Department of Labor (1982), pp. 28-9; U.S. Department of Labor (1979), chapters 1-2; Norwood and Early (1984), pp. $757-59$; and Stinson (1984).

is Official state estimates of unemployment rates are not seasonally adjusted, while official estimates of the U.S. unemployment rate are typically reported in a seasonally adjusted form. Consequently, reported state and national unemployment rates generally will differ for this reason as well. All of the comparisons made in this paper are of seasonally adjusted data. State unemployment rates are seasonally adjusted using the $X-11$ program. This is the same method used by the Department of Labor to adjust national data.
}

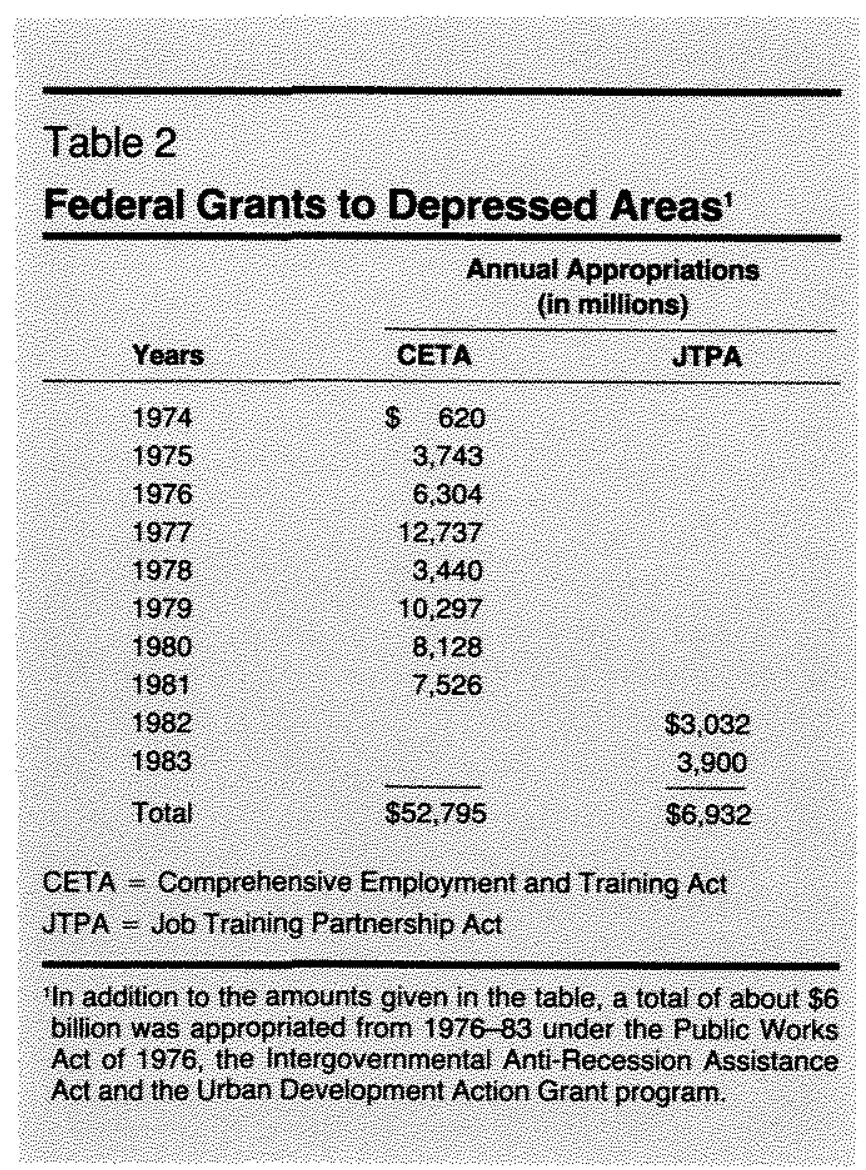

prior to 1978 , laws regarding eligibility for unemployment insurance differed across states. As a result, some states counted people as unemployed who would not be counted as such in other states. This meant that estimates of the unemployment rate were not strictly comparable across states.

The problem of noncomparable unemployment estimates became troublesome in the $1970 \mathrm{~s}$, when federal agencies began using these estimates to determine a state's eligibility for benefits under various federal programs. ${ }^{16}$ These programs include the Comprehensive Employment and Training Act, Public Works and Economic Development Act, Urban Development Action Grant Program, the Labor Surplus Area designation, the Job Training Partnership Act and the Intergovernmental Anti-Recession Assistance Act of 1977. Table 2 lists the amounts appropriated for these programs in various years. The amounts are substantial, so it is not surprising that the noncomparability of state unemployment data became a matter of concern.

16U.S. Department of Labor (1982), pp. 10 and 31. 


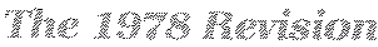

The problem of comparability prompted the Department of Labor to revise the method used to generate estimates of unemployment for the various states In January 1978, the 10 largest states dropped the Handbook Method entirely and began using monthly CPS data to estimate unemployment rates. In the remaining 40 states and the District of Columbia, where it was felt that the size of the sample would not support the direct use of the CPS estimates, a modified form of the Handbook estimating technique was applied. ${ }^{\text {"T }}$ This modification requires the state to multiply its Handbook estimate of the unemployment rate by a ratio of the six-month moving average of the CPS estimate to the corresponding moving average of the Handbook estimate (see appendix on page 14 for detaill.

Since this change in estimating technique shifted the estimated level of unemployment for any given state, the official state unemployment estimates were revised backward in time. This had the effect of splic ing the new official series with the old series at a point prior to 1978. Had this not been done, the official state series would have shown a sharp break in 1978 .

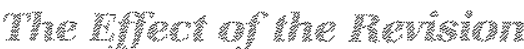

The purpose of the 1978 revision was to make estimates of unemployment rates more comparable across states. According to the Department of Labor, the revision accomplished this by making state estimates conform more closely to the CPS estimate, the method of estimating unemployment at the national level. This was clearly the case for the 10 large states that began using CPS estimates directly. Though less obvious, it may also be true for the $\mathbf{4 0}$ smaller states and the District of Columbia. Under certain assumptions, the official monthly unemployment estimates collapse to the monthly CPS estimate for these smaller states. This is true even if the monthly Handbook estimate is upward- or downward-biased relative to the monthly CPS estimate (see appendix).

If, for example, the Handbook Method produces an estimate of a state's unemployment rate that is consistently 10 percent less than the CPS estimate for the state, this revision in the estimating technique has the effect of raising the official state estimate of the unemployment rate by 10 percent. The reverse is true if the Handbook estimate is consistently higher than the CPS estimate by some constant proportion. It is even

17tbid., p. 30 . possible for the revision to cause estimates of unemployment across all states to rise or fall relative to the national "average." This is true because the method of estimating unemployment at the national level is not an average of state estimates.

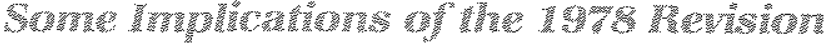

The revision caused the official unemployment rate estimates for the 40 small states and the District of Columbia to rise on average relative to the national rate. This can be shown by examining state Handbook estimates of unemployment. . $^{\text {si }}$

By defnition, Handbook estimates of unemployment at the state level are the same as official estimates of unemployment for data prior to 1978. After 1978, official estimates may diverge from the Handbook estimates by the adjustment factor. It has been shown earlier that official state estimates rose signifcantly relative to the national rate after 1978 . If, how ever, the relationship between the Handbook estimates and the national estimate did not change after 1978, while official state estimates rose relative to Handbook estimates, the case that the shift in the relationship between official state and national unemployment rates was due to the reporting change land not to a structural change in the economy) is quite strong.

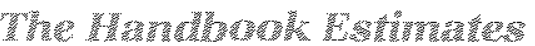

Chart 3 is identical to chart 1 except that it includes a plot of the Handbook estimate of the average unemployment rate for the states in the Eighth Federal Reserve District (HB District). The official estimate of unemployment for the District (labeled District) and the Handbook estimate are virtually identical up to 1977. After 1977, the two estimates diverge with the official estimate rising sharply relative to the U.S. average. The Handbook estimate, however, shows no sharp break at this time. Rather, it remains below the U.S. average and, in 1981 , appears to fall slightly relative to the national unemployment rate.

Notice that the official and Handbook unemployment estimates begin to diverge in 1977 even though the reporting change did not occur until January 1978 . Recall, however, that the official unemployment series for individual states were revised backward. This eliminated a sharp break in the series that would have occurred in 1978 .

${ }^{18}$ These estimates are no longer pubished. However, they are still
computed and were supplied by the Department of Labor upon request. 
Chart 3

\section{Unemployment Rate}

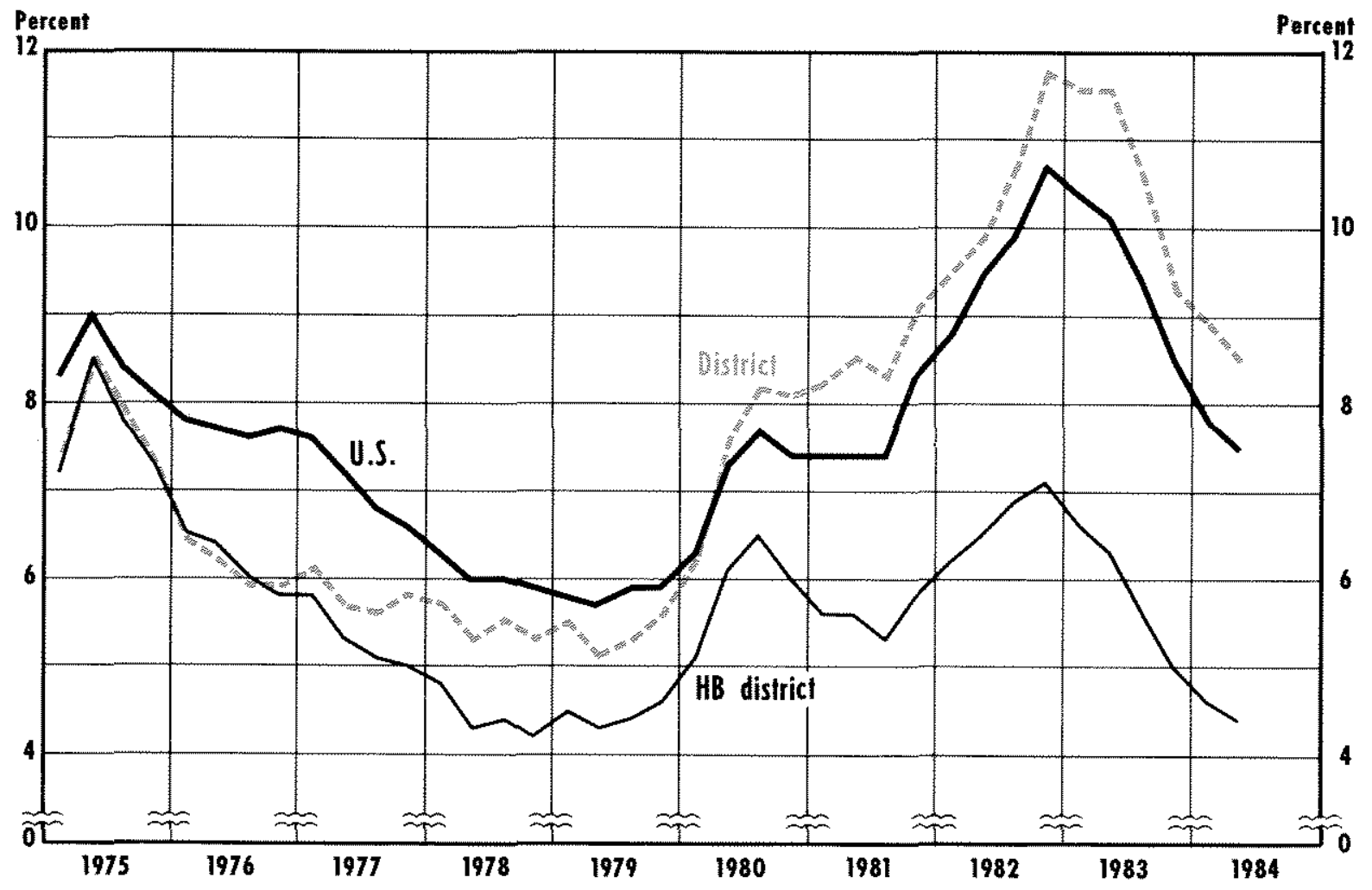

Chart 4 is similar to chart 2 except that it includes a plot of the Handbook estimate of the average unemployment rate for the 40 small states and the District of Columbia [labeled 40 states plus D.C. (HB)]. Again, this plot coincides with a plot of the official estimate until 1977 when the official estimate rises relative to both the Handbook and U.S. estimates.

The data plotted in charts 3 and 4 indicate that, when the same technique of estimating unemployment is applied, the shift in the unemployment series in both the District and other small states relative to the U.S. average vanishes. These data suggest that official estimates of state unemployment produce misleading evidence on changes in the relative severity of the unemployment problem in the late $1970 \mathrm{~s}$ and early 1980s.

Interestingly, the Handbook series, which employs the same estimating technique across the whole period, suggests some improvement in the average unemployment rate in the small states relative to the U.S. rate. This was examined by splitting the period L/1975 IV/1984 in half and comparing the average differences between the U.S. and Handbook unemployment estimates in the two subperiods. The data presented in table 3 indicate that the District unemployment rate declined significantly relative to the national rate in the more recent subperiod. The same was true in the 40 small states and the District of Columbia. This, of course, conflicts with the results obtained by comparing the national unemployment rate to the average of the official estimates of the unemployment rate for the various states.

It is important to keep in mind that estimates of the U.S. unemployment rate and estimates for the small states (generated by either the old Handbook Method 
Chart 4

\section{Unemployment Rate}

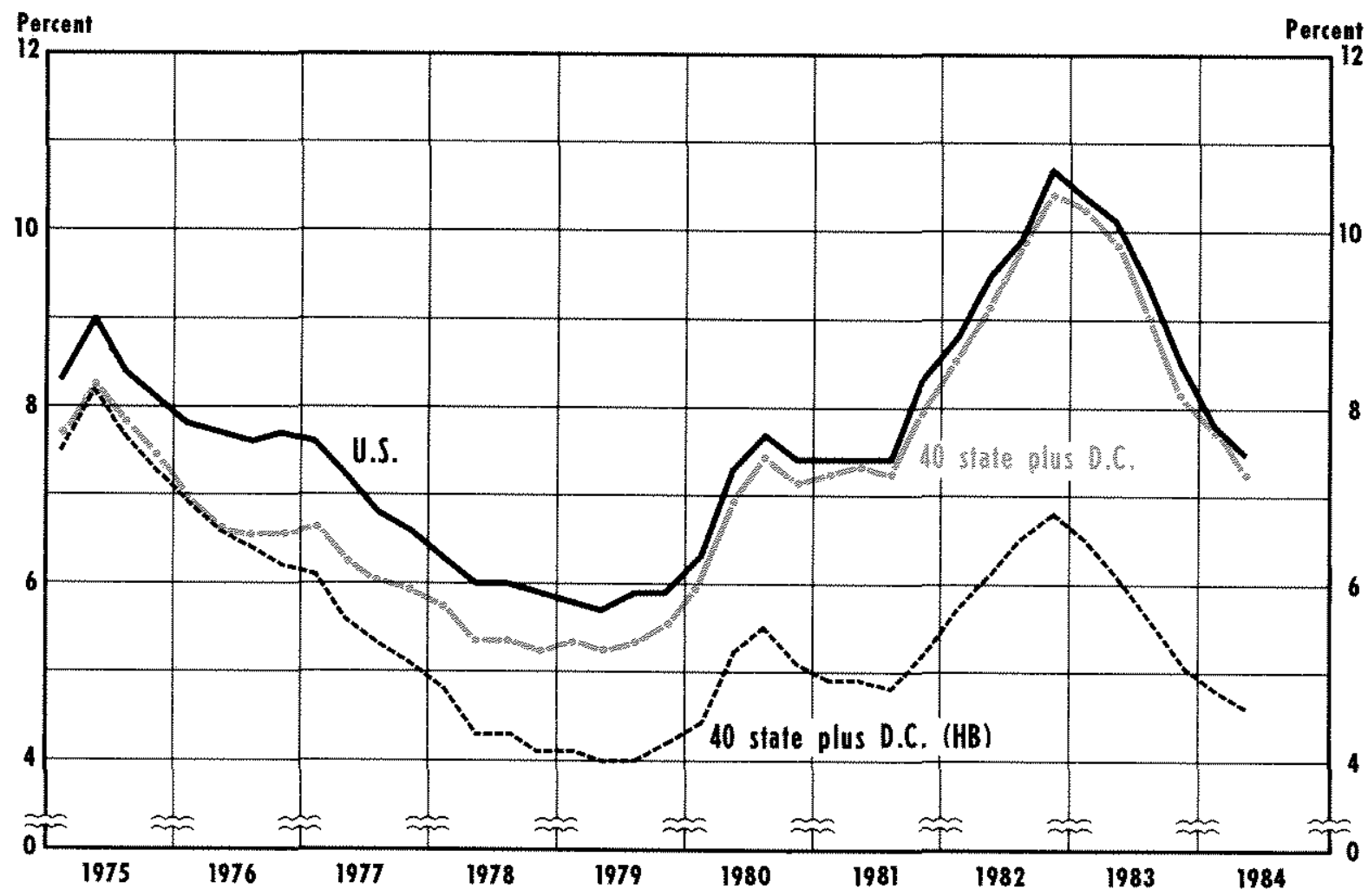

Table 3

A Comparison of Average Differences Between National and Local Area Unemployment Rates

\begin{tabular}{|c|c|c|c|}
\hline & V1975-111/979 & $1111979-117984$ & Change \\
\hline Diferencel & 1,42 & 2.46 & 1041 \\
\hline Difterence 11 & 1,36 & 287 & 1,51 ; \\
\hline
\end{tabular}

Difference I. The average diference between the US Unemployment late and the handbook estimate of the District unemployment rate

Difference II - The average difference between the US Uhemploynent rate and the Handbook estinate of the unemployment rate for the 40 small states and the District of Columbia

Significantly different trom zero at the 5 percentlevel. 
or new Handbook adjusted method) are not strictly comparable either before or after the 1978 change. Consequently, a good deal of care should be used in interpreting the results in table 3 . The table 3 comparison is presented to indicate that, if the same technique is applied in estimating local area unemployment rates, the results show no increase in the unemployment rates for the small states relative to the national unemployment rate in the late $1970 \mathrm{~s}$.

\section{CONCLUSION}

Official estimates of local area unemployment rates for 40 small states, including those in the Eighth Federal Reserve District, and the District of Columbia show a sharp increase relative to the national unemployment rate beginning in the late 1970s. Further, unemployment rates in the small states remained persistently high relative to the national rate throughout the 1979-84 period.

Many observers have attributed the increase to various structural changes in the national economy that have had large adverse consequences for particular states. This article shows that the upward shift in the official estimates of the unemployment rate for the 40 small states and the District of Columbia was due instead to a change in the method of estimating local area unemployment. In short, pre- and post-1978 official estimates of local area unemployment rates are not comparable. When a consistent method of estimating local area unemployment rates is applied over the entire period, the resulting series shows no break in 1978.

\section{RQNWTENCWS}

Clarkson, Kenneth W. and Roger E. Meiners. Inflated Unemployment Statistics, The Effects of Welfare Work Registration Requirements (Law and Economics Center, University of Miami School of Law, March 1977).
"Institutional Changes, Reported Unemployment, and Induced Institutional Changes," Camegie-Rochester Conference Series on Public Policy (1979), pp. 205-35.

Ellis, Leslie. "Economic Recovery Is Only Seen As a Painful Myth to Some," Louisville Couner Joumal, October 7, 1984.

Flaum, David. "Recession Hit Area Hard," Memphis Commercial Appeal, June 12, 1984

Greenwood, M. J. and G. L. Hunt. "Migration and Interregional Employment Redistribution in the United States," American Economic Review (December 1984), pp. 957-69.

Kester, William H. "Jobless Rate Here Declines to $7.6 \%$," St. Louis Post-Dispatch, August 30, 1984a.

"Good News for St. Louis on Two Fronts," St. Louis Post-Dispatch, September 2, 1984 b.

Luecke, Pam. "Campaign Cliche Overlooks Region's Many Complexities," Louisville Courier Joumal, October 7, 1984.

Norwood, Janet L. and John F. Early. "A Century of Methodological Progress at the U.S. Bureau of Labor Statistics," Journal of the American Statistical Association (December 1984), pp. 748-61.

Oi, Walter $Y$. "Government Labor Policies and Equilibrium Unem. ployment Rates," Carnegie-Rochester Conference Series on Public Policy (1979), pp. 237-52.

Olson, Mancur. "The South Will Fall Again: The South as Leader and Laggard in Economic Growth," Southem Economic Joumal (April 1983), pp. 917-32.

Santoni, G. J. "Business Cycles and the Eighth District," this Review (December 1983), pp. 14-21.

Stinson, John F. Jr. "Comparison of Nonagricultural Employment Estimates From Two Surveys," Employment and Earnings (March 1984), pp. 6-9.

Supel, Thomas M. "The Impact of Welfare Work Registration Rules on Labor Market Data," Staff Reports, Federal Reserve Bank of Minneapolis (October 1977).

Szymczak, Patricia. "Venture Capital Skips Midwest," St. Louis Globe-Democrat, October 3, 1984.

U.S. Department of Labor, Bureau of Labor Statistics. Handbook of Methods (December 1982), pp. 3-36.

U.S. Department of Labor, Bureau of Labor Statistics. Manual for Developing Local Area Unemployment Statistics (1979).

Wagman, Paul. "RCGA Study Says Area Needs Venture Capital," St. Louis Post-Dispatch, September 15, 1984.

Wonnacott, Thomas H. and Ronald J. Wonnacott. Introductory Statistics for Business and Economics, 2nd ed. (John Wiley and Sons, lnc., 1977). 


\section{A PDP}

In 1978, the technique used to estimate official unemployment rates in each of 40 small states and the. District of Columbia was modified. Rather than relying solely on state estimates produced by the Handbook Method, these estimates were adjusted by the ratio of two moving averages. Specifically, for each state i,

where

$$
\mathrm{U}(\mathrm{t})_{\mathrm{i}}=\mathrm{UHB}(\mathrm{t})_{\mathrm{i}} \frac{\sum_{\mathrm{k}=0}^{5} \operatorname{UCPS}(\mathrm{t}-\mathrm{k})_{\mathrm{i}}}{\sum_{\mathrm{k}=0}^{5} \mathrm{UHB}(\mathrm{t}-\mathrm{k})_{\mathrm{i}}}
$$

$$
\begin{aligned}
\mathrm{U}(\mathrm{t})_{\mathrm{i}}= & \text { the official state estimate of the un- } \\
& \text { employment rate in month t; } \\
\mathrm{UHB}(\mathrm{t})_{\mathrm{i}}= & \text { the Handbook estimate of the un- } \\
& \text { employment rate for the state in } \\
& \text { month } \mathrm{t} \\
\mathrm{UCPS}_{\mathrm{i}}= & \text { the CPS estimate of the unemploy- } \\
& \text { ment rate for the state in month } t .
\end{aligned}
$$

Under certain assumptions, the official unemployment estimate collapses to the CPS estimate for these small states. Suppose for state $i_{1}$ UHB $_{1}$ is related to
UCPS $_{i}$ as follows:

$$
\mathrm{UCPS}_{1}=\alpha_{i} \mathrm{UHB}_{1}
$$

where $\alpha_{1}$ is a constant. If $\alpha_{1}>1, \mathrm{UHB}_{1}$ is biased downward relative to UCPS. If $\alpha_{i}<1$, UHB is biased upward relative to UCPS. The official unemployment estimate for any state, $i$, is

$$
\begin{gathered}
U(t)_{i}=\operatorname{UHB}(t)_{i} \frac{\sum_{k=0}^{5} \alpha_{i} \text { UHB }(t-k)_{i}}{\sum_{k=0} \text { UHB }(t-k)_{i}} \text { or } \\
\mathrm{U}(t)_{k}=\alpha_{i} \text { UHB }(t)_{i}=\operatorname{UCPS}(t)_{i}
\end{gathered}
$$

The expected value of the official estimate for state $i$ is

$$
\mathrm{E}(\mathrm{U})_{i}=\alpha_{i} \mathrm{E}(\mathrm{UHB})_{\mathrm{i}}=\mathrm{E}(\mathrm{UCPS})_{\mathrm{i}}
$$

and its variance is

$$
\operatorname{Var}(\mathrm{U})_{\mathrm{i}}=\alpha_{\mathrm{i}}^{2} \operatorname{Var}(\mathrm{UHB})_{\mathrm{i}}{ }^{2}
$$

See Wonnacott and Wonnacott (1977), pp. 127-30. 